\title{
Effect of temperature on growth of cheatgrass and Idaho fescue
}

\author{
MOHAMED NASRI AND PAUL S. DOESCHER
}

\author{
Authors are former graduate research assistant and associate professor at Oregon State University; Convallis 97331 - \\ 2218 .
}

\begin{abstract}
Development of deep and extensive root systems especially at cold temperatures has been considered an advantage to successful establishment of grass species in arid environments. This study determined the effects of temperature on seedling root and shoot growth of cheatgrass (Bromus tectorum L.) and 5 collections of Idaho fescue (Festaca idahoensis Elmer). Four collections of Idaho fescue were from degraded sites while the fifth Idaho fescue collection was from a site in high ecological condition. Seedlings were grom in environmental chambers (16 hours day/8 hours night) at 5,10 , and $15^{\circ} \mathrm{C}$. Root depth was recorded weekly for 9 weeks, and seedlings were harvested after 63 days. Tiller and leaf number, below and above-ground biomass, and total root length rrere evaluated. At temperatures of 5,10 , and $15^{\circ} \mathrm{C}$, cheatgrass grew faster and produced a greater mass of roots and shoots than Idaho fescue. Root and shoot growth were similar for the 5 Idaho fescue collections at all temperatures. Idaho fescue collections proảuced more tillers than cheatgrass, except at $5^{\circ} \mathrm{C}$. These resulss indicated that cheatgrass produces greater root and shoot growth mass, but tillers less at warmer temperatures than Idaho fescue.
\end{abstract}

Key Words: Bromus tectorum, Festuca idahoensis, growth chambers, root and shoot growth, population ecology.

On many rangelands of the world, loss of native perennial vegetation is accompanied by invasion of aggressive annual weeds. One example of large scale vegetation change is still occurring on rangelands of the Intermountain West. On substantial areas, native grasses such as Idaho fescue (Festuca idahoensis Elmer) have been replaced by various undesirable species, including the annual cheatgrass (Bromus tectorum L.) (Valentine 1989, Mack 1981). This has led to a loss of desirable forage and to an increased interest in enhancing restoration of native species such as Idaho fescue (Jordan et al. 1987, Humphrey 1945, Daubenmire 1942).

\footnotetext{
The authors thank Drs. Doug Johnson, Dale Moss and Miarshall Haferkamp, and 2 anonymous revievers for constructive reviews of earlier versions. Jay Goodwin and Mohamed Jabbes made helpful suggestions during the course of this research. Dr. Dave Thomas, Professor, Department of Statisties, Oregon State University, provided statistical advice. This material is based upon work supported by the Cooperative State Research Service, U.S. Department of Agriculture under Agreament No. \&S-3\&300-3623.

Submitted as Technical Paper 10205, Oregon Agricultural Experiment Station. Oregon State University, Corvallis. Ore. 97331.

Reprint requests to Paul Doescher.

Manuscript accepted 2 Dec. 1994.
}

Efforts to reestablish native perennial grasses have met with limited success. One reason for this includes vigorous seedling development of cheatgrass. Seedlings of cheatgrass grow faster at cold temperatures even with little water, and produce roots which grow deeper, and are larger and heavier than roots of native perennial species (Melgoza and Nowak 1991, Aguirre and Johnson 1991a,b, Svejcar 1990, Harris 1977). As a result, rapid root penetration at low temperature is reported as essential in successfully establishing perennial grasses when cheatgrass is abundant (Dewitt 1969, Harris 1967).

In spite of the apparent advantage that cheatgrass has over native perennial grasses, some remnant populations of Idaho fescue persist on degraded sites in central Oregon. Because Idaho fescue can develop ecotypes (Turresson 1922) based upon geographic segregation (Tisdale 1959, 1960) and local environmental conditions (Doescher 1983), we speculated that these remnant populations may have different seedling growth characteristics than Idaho fescue from undisturbed sites. Specifically, we hypothesized that roots of remnant plants of Idaho fescue may grow faster and deeper at cold temperatures than plants from pristine areas. This may allow remnant populations to establish on degraded rangelands in association with cheatgrass (Harris 1967). The objectives of the present study were:1) to compare the effect of temperature on root and shoot development of Idaho fescue in comparison to cheatgrass, and 2) to compare Idaho fescue seedlings from 4 degraded sites to Idaho fescue from an undisturbed site.

\section{Materials and Methods}

Seeds of Idaho fescue and cheatgrass were collected in 1989. Idaho fescue was collected from 5 locations near Prineville, Oregon: (1) Island, (2) Lone Pine, (3) McCoin Orchard, (4) Blanchard Well, and (5) Combs Flat (Nasri 1993, Goodwin 1993). All sites, except the Island (Driscoll 1964), were assumed grazed by livestock for the last 125 years. Cheatgrass seeds were collected from Combs Flat.

The study was conducted as a randomized-complete-block design with 5 blocks. Temperature regimes (3) and grass collections (5 Idaho fescue and 1 cheatgrass) were factorially arranged in each block. Plants were grown in glass tubes $(51 \mathrm{~mm}$ outer diameter and 60 or $90 \mathrm{~cm}$ in length) and filled with surface soil 
collected from the top $10 \mathrm{~cm}$ at the Combs Flat site. This soil was classificd as a mixed, mesic Lithic Haploxeroll (Vaitkus 1986), and the texture was a very stony loam (Goodwin 1993). The bottom of each tube was closed with a rubber stopper with a hole to allow drainage. Each tube was wrapped in aluminum foil to prevent exposing roots to light. Soils were brought to field capacity 2 days prior to planting. Five seeds of each collection were placed on the soil surface, covered with 1-cm air-dried soil, and germinated in the greenhouse. Seeds of cheatgrass were sown 5 days after Idaho fescue to obtain seedlings of approximately the same age.

Seedlings were considered established on 10 September 1991, at which time the glass tubes were transferred to growth chambers set at constant temperatures of 5,10 , and $15^{\circ} \mathrm{C}$. Irradiance at the plant level was about 130 umoles $\mathrm{m}^{-2} \mathrm{~s}^{-1}$. Glass tubes were placed in wooden racks at an angle of $17^{\circ}$ from vertical to insure that roots grew against the tubes. After 7 days, seedlings were thinned to 1 seedling per tube (Day 1 of the experiment). The soil surface was watered with about $25 \mathrm{ml}$ of water every 7 days to reảuce surface crusting.

Plant response to treatment was determined by measuring rooting depth every 7 days, and above and belowground biomass, foliage height, tiller number, leaf number, and total root system length at the end of 63 days. When the study was completed plants were clipped to ground level, and tubes soaked in water for 3 days to aid in removing soils from roots. Soil was washed from roots with a fine mist of water above a $7.5-\mathrm{mm}$ screen. Root length was estimated by recording weight of the intact fresh root system, taking 3 subsamples of the root system, and measuring length and total weight of the subsamples. A ratio of root weight to root length was calculated based on subsample averages, and this value multiplied by total fresh root weight to derive root length. Above-and below-ground biomass was oven-dried at $S 0^{\circ} \mathrm{C}$ for 48 hours before being weighed.

Root depth was analyzed using a repeated measures analysis of variance. Total root length, above and below-ground dry weight, shoot height, leaf, and tiller number were also analyzed using anaysis of variance (SAS 1987). Because temperature treatments were not replicated, statistical comparisons were made only berween species response within a temperature.

Upon detection of a significant $F$ value, mean separation involved both the use of planned comparisons and the F-protected least significant difference (Steele and Torrie 1980). Planned comparisons were used to address a priori questions suggested by the original hypothesis:1) does Idaho fescue differ in growth compared with cheatgrass, and 2) does Idaho fescue from degraded populations grow better than Idaho fescue from the undissurbed population. When planned comparisons indicated a difference among Idaho fescue populations or for comparisons among temperatures, an LSD was performed (Thomas pers. comm.). The alpha level was set at $P \leq 0.05$. Only significant differences are reported in the text.

\section{Results}

Differences in root and shoot growth between cheatgrass and Idaho feseue were found at all temperatures except for leaf numher and root:shoot ratio (Table 1). Very few differences in growth parameters were detected among Idaho fescue collections.
Table 1. Significance levels for various plant characteristics in a randomized complete block design ANOVA for comparisons between cheatgrass and 5 Idaho fescue collections grown under 3 temperatures.

\begin{tabular}{lccc}
\hline \hline & \multicolumn{3}{c}{ Temperature } \\
\cline { 2 - 4 } Plant & & $10^{\circ} \mathrm{C}$ & $15^{\circ} \mathrm{C}$ \\
\hline Characteristics & $5^{\circ} \mathrm{C}$ & $*$ & $*$ \\
Total Root Length & $* 1$ & $*$ & NS \\
Root Dry Weight & $*$ & $*$ & $*$ \\
Root Depth ${ }^{2}\left(\mathrm{~T}^{*} \mathrm{C}^{3}\right)$ & $*$ & $*$ & $*$ \\
W1 & $*$ & $*$ & $*$ \\
W2 & NS & $*$ & $*$ \\
W3 & NS & $*$ & $*$ \\
W4 & NS & $*$ & $*$ \\
W5 & $*$ & $*$ & $*$ \\
W6 & $*$ & $*$ & $*$ \\
W8 & $*$ & $*$ & $*$ \\
W9 & $*$ & & $*$ \\
Daily Growth & $*$ & $*$ & $*$ \\
Aboveground & & NS & $*$ \\
Dry Weight & $*$ & NS & NS \\
Height & NS & NS & NS \\
Tiller Number & NS & & $*$
\end{tabular}

$\mathrm{1}_{*}=$ Significant at the 0.05 level of probability; NS $=$ Not significant at the 0.05 level of probability:

2Root Depth:Values for root depth were analyzed as a repeated measure design. ${ }^{3}(\mathrm{~T} * \mathrm{C})=$ Time $\times$ Collection.

\section{Belowground Response}

Root penetration of Idaho fescue and cheatgrass increased during the 9-week experiment for each temperature (Fig. 1). Cheatgrass roots penetrated to an average depth of $34 \mathrm{~cm}$ at $5^{\circ} \mathrm{C}$, compared with $88 \mathrm{~cm}$ by week 8 at $10^{\circ} \mathrm{C}$, and $88 \mathrm{~cm}$ by week 7 at $15^{\circ} \mathrm{C}$. Cheatgrass seedlings exceeded Idaho fescue seedlings in rooting depth, root length, belowground biomass, and daily root growth rates (Fig. 1 and Table 2). No differences were detected among Idaho fescue collections in root length, daily root growth rates, belowground biomass, or rooting depth at 5 and $10^{\circ} \mathrm{C}$. Only at $15^{\circ} \mathrm{C}$ did the Island collection produce a greater rooting depth than the Combs Flat collection (Fig. 1).

\section{Aboveground Response}

Aboveground biomass of cheatgrass seedlings exceeded those of Idaho fescue at 5 and $10^{\circ} \mathrm{C}$, and all but the Island collection at $15^{\circ} \mathrm{C}$ (Table 3). Shoot height of cheatgrass seedlings was greater than Idaho fescue collections at all temperatures (Table 4). Tiller production was greater for cheatgrass than Idaho fescue at $5^{\circ} \mathrm{C}$, but tiller production was greater for Idaho fescue compared with cheatgrass at 10 and $15^{\circ} \mathrm{C}$ (Table 4). Among Idaho fescue collections, biomass was similar at 5 and $10^{\circ} \mathrm{C}$, shoot height was similar at 5 and $15^{\circ} \mathrm{C}$, and tiller number was similar across all temperatures. The Island collection produced the largest aboveground biomass at $15^{\circ} \mathrm{C}(1,111 \mathrm{mg})$, and the Combs Flat collection was shortest $(81 \mathrm{~mm})$ of all Idaho fescue collections at $10^{\circ} \mathrm{C}$.

\section{Discussion}

Cheatgrass seedings were more productive in this study than Idaho fescue seedlings across all temperatures, and very few dif- 

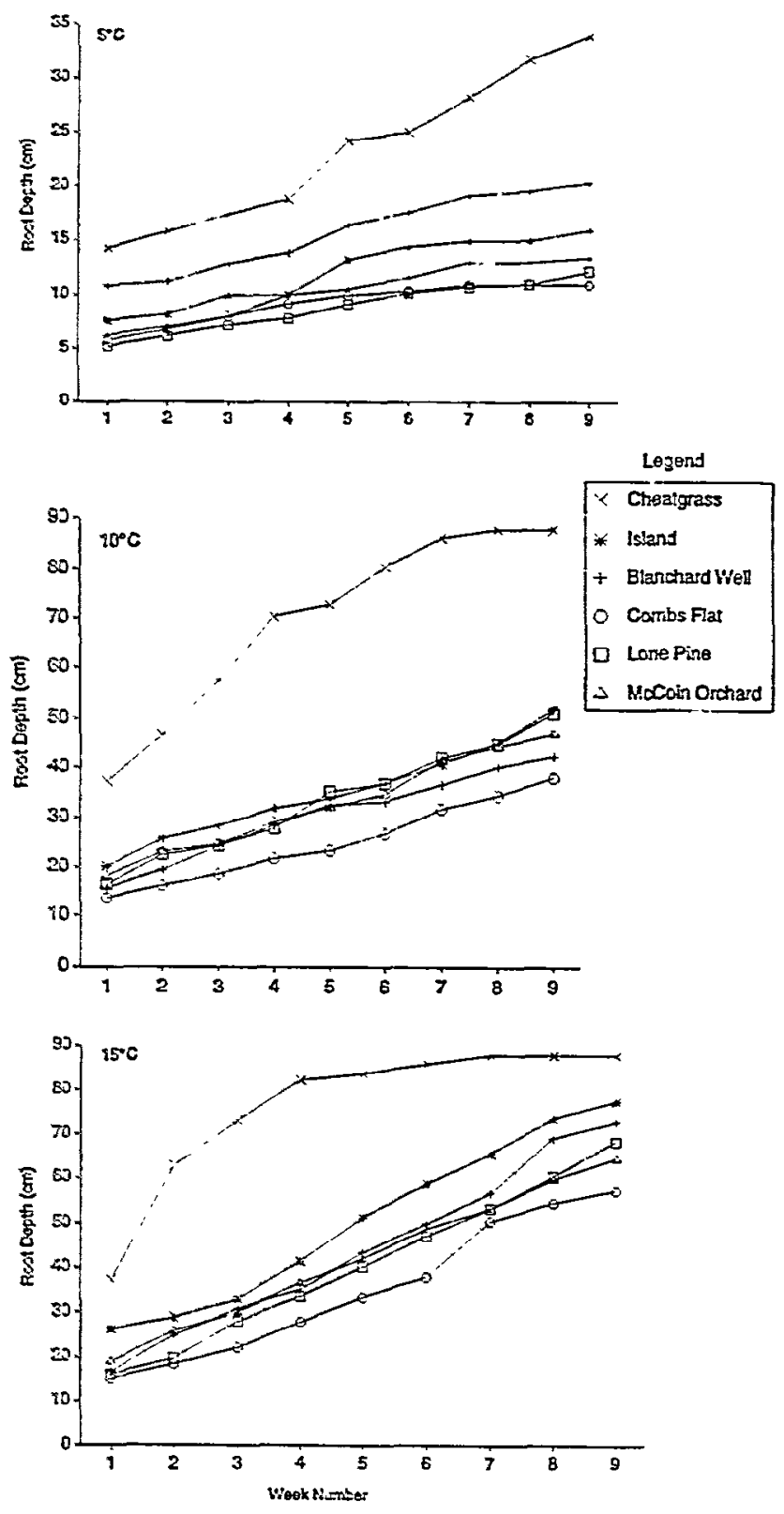

Fig. 1. Rost depth of Idaho fescue and cheatgrass collections over 63 days at temperatures of 5,10 , and $15^{\circ} \mathrm{C}$.

ferences were noted among Idaho fescue collections. Idaho fescue seedlings, however, produced more tillers than cheatgrass at 10 and $15^{\circ} \mathrm{C}$.

Cheatgrass seedlings are frequently found to have a competitive advantage over perennial grass seedlings, especially at temperatures as low as $3^{\circ} \mathrm{C}$ ( Harris 1967, 1977; Melgoza and Nowak 1991; Aguirre and Johnson 1991a,b). Cheatgrass root and shoot growth was faster and greater at cold temperatures than those of native perennials. Cheatgrass produced greater root growth than bluebunch wheatgrass [Pseudoroegneria spicata (Pursh) Love], and that was generally associated with greater leaf growth (Harris 1967). Cheatgrass was more efficient (per unit of biomass) in producing leaf area and root length than Agropyron desertorum (Fisch. ex Link) Schult (Svejcar 1990), and that is one of the factors contributing to the competitive advantage of cheatgrass
Table 2. Belowground growth of cheatgrass and Idaho fescue at 5 , 10 , and $15^{\circ} \mathrm{C}$ at the end of 63 days. Values among Idaho fescue collections were not different; the grand mean of all collections is presented.

\begin{tabular}{|c|c|c|c|}
\hline \multirow[b]{2}{*}{ Temp. $\left({ }^{\circ} \mathrm{C}\right)$} & \multicolumn{2}{|c|}{ Grass collections } & \multirow[b]{2}{*}{ (MSE) } \\
\hline & Cheatgrass & Idaho Fescue & \\
\hline \multicolumn{4}{|c|}{ Root length $(\mathrm{cm}) \ldots \ldots$} \\
\hline 5 & $1,086 a^{1}$ & $101 \mathrm{~b}$ & 309,968 \\
\hline 10 & $9,147 \mathrm{a}$ & $2,418 b$ & $1,961,739$ \\
\hline 15 & $9.481 \mathrm{a}$ & $3,800 \mathrm{~b}$ & $5,565,513$ \\
\hline \multicolumn{4}{|c|}{$\ldots$} \\
\hline 5 & $32 \mathrm{a}$ & $8 \mathrm{~b}$ & 0.1 \\
\hline 10 & $1,650 a$ & $622 \mathrm{~b}$ & 126.7 \\
\hline 15 & $1,697 \mathrm{a}$ & $1,145 \mathrm{~b}$ & 285.9 \\
\hline \multicolumn{4}{|c|}{-Daily root growth $\left(\mathrm{mm} \mathrm{day}^{-1}\right)$} \\
\hline 5 & $5.4 \mathrm{a}$ & $2.3 \mathrm{~b}$ & 1.3 \\
\hline 10 & $14.0 \mathrm{a}$ & $7.3 \mathrm{~b}$ & 2.8 \\
\hline 15 & $14.0 \mathrm{a}$ & $10.8 \mathrm{~b}$ & 4.0 \\
\hline
\end{tabular}

${ }^{1}$ Means within a row followed by the same letter are not different at the 0.05 level of significance.

seedlings over seedlings of most perennial bunchgrasses. Cheatgrass successfully competed with established native perennials, needle-and-threadgrass (Stipa comata Trin and Rupr) and rabbitbrush (Chrysothamnus viscidiflorus (Hook.) Nutt) and partially interfered with root development in the native species (Melgoza and Nowak 1991). Adventitious roots of cheatgrass elongated earlier at cold temperatures $\left(10 / 5^{\circ} \mathrm{C}\right)$, and exhibited greater total root length than 'Hycrest', a hybrid cultivar of crested wheatgrass [Agropyron desertorum $\times$ Agropyron cristatum (L.) Gaert.], 'Whitmar', a cultivar of bluebunch wheatgrass and 'Secar', a cultivar of snake river wheatgrass [Elymus lanceolatus (Scribner) and J. G. Smith Gould] (Aguirre and Johnson 1991b). However, Buman et al. (1988) found that root growth of Hycrest crested wheatgrass lagged only behind that of cheatgrass during the first week of a controlled environment experiment under warmer temperature conditions.

Although cheatgrass produced greater root and shoot mass and root length, Idaho fescue produced a similar root:shoot ratio to cheatgrass at all temperatures. Root:shoot ratios may, however, not be a meaningful way to judge competitive relationships between species, but root length:leaf area ratio may be a better index for assessing competitive success (Svejcar 1990). Unfortunately, leaf areas were not determined in this study. Idaho fescue did produce a greater number of tillers than cheatgrass at 10 and $15^{\circ} \mathrm{C}$. This may result in a rapid increase in the vegetative size of Idaho fescue in non-competitive environments. Other

Table 3. Aboveground biomass of 6 grass collections at $5,10,15^{\circ} \mathrm{C}$ at the end of 63 days.

\begin{tabular}{|c|c|c|c|c|c|c|c|}
\hline \multirow[b]{2}{*}{ Temp. $\left({ }^{\circ} \mathrm{C}\right)$} & \multicolumn{6}{|c|}{ Grass collections } & \multirow[b]{2}{*}{ (MSE) } \\
\hline & $\begin{array}{l}\text { Cheat- } \\
\text { grass }\end{array}$ & Island & $\begin{array}{c}\text { Blanchard } \\
\text { Well }\end{array}$ & $\begin{array}{c}\text { Combs } \\
\text { Flat }\end{array}$ & $\begin{array}{l}\text { Line } \\
\text { Pine }\end{array}$ & $\begin{array}{c}\text { MCC } \\
\text { Orchard }\end{array}$ & \\
\hline & \multicolumn{7}{|c|}{ 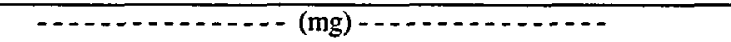 } \\
\hline 5 & $72 a^{1}$ & $16 \mathrm{~b}$ & $19 \mathrm{~b}$ & $10 \mathrm{~b}$ & $15 \mathrm{~b}$ & $23 \mathrm{~b}$ & 3 \\
\hline 10 & 2,277 a & $1,177 \mathrm{~b}$ & 61 & 54 & $736 \mathrm{~b}$ & $967 \mathrm{~b}$ & 216 \\
\hline 15 & $1,485 \mathrm{a}$ & $1,111 \mathrm{a}$ & $694 b$ & $591 \mathrm{~b}$ & $896 \mathrm{~b}$ & $758 \mathrm{~b}$ & 110 \\
\hline
\end{tabular}

1 Means within a row followed by the same letter are not different at the 0.05 level of significance. 
Table 4. Shoot height and tiller number of 6 grass collections at 5 , 10 , and $15^{\circ} \mathrm{C}$ at the end of 63 days. Values among Idaho fescue collections were not different; the grand mean of all collections is presented.

\begin{tabular}{lccc}
\hline \hline & \multicolumn{2}{c}{ Grass Collections } & \\
\cline { 2 - 3 } Temp. $\left({ }^{\circ} \mathrm{C}\right)$ & Cheatgrass & Idaho Fescue & (MSE) \\
\hline 5 & $118 \mathrm{a}$ & $79 \mathrm{~b}$ & 477 \\
10 & $169 \mathrm{a}$ & $127 \mathrm{~b}$ & 748 \\
15 & $164 \mathrm{a}$ & $113 \mathrm{~b}$ & 534 \\
& & & \\
5 & $\ldots$ & $3 \mathrm{~b}$ & 0.1 \\
10 & $4 \mathrm{a}$ & $52 \mathrm{~b}$ & 532 \\
15 & $21 \mathrm{a}$ & $62 \mathrm{~b}$ & 404 \\
\hline S.jeans within a row followed by the same letter are not different at the 0.05 level of sig-
\end{tabular}
rificance.

Ferennial bunchgrasses such as Hycrest, Whitmar, and Secar exhibit slower leaf and tiller development than cheatgrass (Aguirre and Johnson 1991a,b). Rapid tillering rates of Idaho fescue may help promote establishment of this species if competition from cheatgrass was controlled. However, rapid root and shoot growth characteristics of cheatgrass, especially in cooler temperatures, would still probably confer an ecological advantage to this species in the field.

\section{Literature Cited}

Aguirre, L., and D.A. Johnson. 1991a. Root morphological development in relation to shoot growth in seedlings of four range grasses.J. Range Manage. 44:341-346.

Aguirre, L., and D.A. Johnson. 1991b. Influence of temperature and cheatgrass competition on seedling development of two bunchgrasses. J. Range Manage. 41:347-354.

Euman, R.A., S.B. Monsen, and R.H. Abernethy. 1988. Seedling competition between mountain rye, 'Hycrest' crested wheatgrass, and downy brome. J. Ronge Manage. 41:30-34.

Daubemmire, R.F. 1942. An ecological study of the vegetation of southem Washington and adjacent Idaho. Ecol. Mongr. 12:54-79.

Dewitt, P.F.F. 1969. Environmental response to low temperature in Agropyron spicatum collected from native stands in western North Ameriea. M. S. Thesis, Washington State University.Pullman, Wash.

Doescher, P.S. 1983. Phyto-edaphic relationships and ecotypic development of Festuca idahoensis in Eastern Oregon habitat types of Aremisia tridentata. Ph.D. Diss.Oregon State University, Corvallis, Ore. Micro-films. Ann Arbor, Mich. (Diss. Abstr. 43:206-8).

Driscoll, R.S. 1964. A relict area in the central Oregon juniper zone. Exol. 45:345-353.

Goadwin, J.R. 1993. Ecotypic variation, adaptation, and persistence of Idaho fescue on degraded central Oregon rangelands. M. S. Thesis. Oregon State University.Corvallis, Ore.

Herris, G.A. 1967. Some competitive relationships between Agropyron spicatum and Bromus tectorum. Ecol. Monogr.37:89-111.

Rerris, G.A. 1977. Root phenology as a factor of competition among grass seedlings. J. Range. Manage.30:172-177.

Humphrey, R.R. 1945. Common range forage types of the inland Pacific Northwest. Northwest Sci. 19:3-11.

Jardan, W.R. MI., M. E. Gilpin, and J. D. Aber. 1987. Restoration ecology research. Cambridge.Univ. Press, Cambridge.

Mack, R.N. 1981. Invasion of Bromus tectorum L. into western North American:An ecologieal chronicle.Agro-ecosystems 7:145-165.
Melgoza, G., and R.S. Nowak. 1991. Competition between cheatgrass and two native species after fire. Implication for observations and measurements of root distribution. J. Range. Manage.44:27-32.

Nasri, M. 1993. Effect of temperature and competition on shoot and root growth of cheatgrass (Bromus tectorum L.) and 5 collections of Idaho fescue (Festuca idahoensis Elmer). M.S. Thesis.Oregon State Univ..Corvallis, Ore.

Nasri, M., and P.S. Doescher. 1994. Effects of competition from cheatgrass on shoot growth of Idaho fescue. J. Range Manage. 48:402-406.

SAS. 1987. SAS/STAT guide for personal computers, version 6 edition. SAS Institute. Cary, N.C.

Steel, R.G.D., and J.H. Torrie. 1980. Principles and procedures of statistics, second edition.McGraw-Hill Book Company Inc. N.Y.

Svejcar, T. 1990. Root length, leaf area, and biomass of crested wheatgrass and cheatgrass seedlings. J. Range. Manage. 43:446-448.

Tisdale, E.W. 1959. Intraspecific variation in Festuca I. Carnegie Inst. of Washington Year Book. 58:356-358.

Tisdale, E.W. 1960. Intraspecific variation in Festuca II.Carnegie Inst. of Washington Year Book.60:399-391.

Turesson, G. 1922. The species and the variety as ecological units. Heriditas. 3:100-113.

Vaitkus, M.R. 1986. Effect of westem juniper on understory production in eentral Oregon. M.S. Thesis. Oregon State Univ.,Corvallis, Ore.

Valentine, J.F. 1989.Range development and improvement, third edition. Academic Press. San Diego, Calif. 